\title{
STRUCTURAL FEATURES AND OPERATIONAL CHARACTERISTICS OF STEEL T91
}

\author{
DVictor Voyevodin, (D) Mikhail Tikhonovsky, (D)Galyna Tolstolutska, (D)Hanna Rostova, \\ Duslan Vasilenko, (D) Oleksandr Kalchenko, (D)Natalya Andrievska, (D) Oleksii Velikodnyi \\ National Science Center "Kharkov Institute of Physics and Technology” \\ 1, Akademicheskaya Str., Kharkov 61108, Ukraine \\ *Corresponding Author: rostova@kipt.kharkov.ua \\ Received May 20, 2020; accepted June 30, 2020
}

The microstructure and radiation resistance of T91 martensitic steel were studied after thermomechanical treatment. The physical and technological foundations of the process of creating of a nanostructured state in T91 reactor steel have been developed. This structure was received by severe plastic deformation of T91 steel by the multiple "upsetting-extrusion" method (developed at the NSC KIPT) in two temperature ranges of deformation: in the region of austenite existing and with a successive decrease in the deformation temperature and an increase in cycles of "upsetting-extrusion" in the field of ferrite existence. For the further heat treatment the particular temperature range and deformation modes were chosen to obtain optimal structure. Also, the optimum temperature of tempering to receive the uniform structure was established. It was found that the average grain size of T91 steel decreases from 20 $\mu \mathrm{m}$ in the initial state to $\sim 140 \mathrm{~nm}$ after 5 cycles of "upsetting-extrusion" in the ferrite interval and to $\sim 100 \mathrm{~nm}$ after 3 cycles of deformation in the austenitic region. It was determined that with an increase in the number of cycles and a decrease in the deformation temperature, a rise in the degree of uniformity of grain size distribution occurs. In this case, the microhardness increases from $2090 \mathrm{MPa}$ to $2850 \mathrm{MPa}$ after 5 cycles of "upsetting-extrusion" in the ferritic interval. In the austenitic region, the microhardness values increase from 3400 to $3876 \mathrm{MPa}$. The swelling of T91 steel in two structural states, martensitic and ferritic, was determined. Thus, steel swelling at a high dose of irradiation with argon ions with an energy of $1.4 \mathrm{MeV}$ (120 displacements per atom, irradiation temperature $460{ }^{\circ} \mathrm{C}$ ) is $\Delta \mathrm{V} / \mathrm{V}=0.26 \%$ in the initial state (martensitic structure) and $0.65 \%$ for samples with a ferritic structure.

KEYWORDS: martensitic steel, thermomechanical treatment, microhardness, nanostructure, severe plastic deformation, radiation resistance.

The creation of GenIV fission and fusion reactors poses new problems in materials science in terms of higher operating temperatures, increased neutron doses, as well as ensuring the safe and efficient operation of reactors. The problem of conventional structural materials, in particular austenitic steels, lies in the fact that they will not be able to be operated under more severe irradiation conditions due to their low radiation resistance. Ferritic and / or martensitic steels are considered as potential structural materials for their good resistance to irradiation, less swelling, better ductility, etc. $[1,2]$. In particular, T91 martensitic steel is considered as a promising material for future new generation nuclear reactors [3]. However, the steels of these classes have a significant drawback - heat resistance, which limits the maximum working temperature to $\sim 500{ }^{\circ} \mathrm{C}$. The main way of solving this problem is thermomechanical treatment, which allows not only to qualitatively improve the mechanical characteristics, but also to increase the radiation resistance of the material.

The standard technological scheme for the heat treatment of T91 martensitic steel consists in normalization at temperatures of $1040-1080{ }^{\circ} \mathrm{C}$ followed by air cooling [4]. In this case, the microstructure of quenched martensite is formed, which leads to high strength but low ductility of steel. To increase ductility, steel is tempered at temperatures of $730-780{ }^{\circ} \mathrm{C}$. As a result, there is a formation of a coarse-grained microstructure with inhomogeneity in grain size. Although ductility increases considerably, the strength characteristics are reduced. A significant improvement in mechanical properties can be expected when an ultrafine-grained or nanostructured state is produced in steel, which usually contributes to an increase in the radiation tolerance of the material $[5,6]$. The creation of such a microstructure is possible using thermomechanical treatment using severe plastic deformation (SPD), carried out by various methods [7 - 9].

A distinctive feature of T91 steel in comparison with other steels of the ferritic-martensitic class is the high sensitivity of its structure to the composition and type of heat treatment, and, as a result, a large data scattering of the swelling values for the same exposure conditions [10-12]. Optimization of the factors of the structural-phase state of T91 steel and study of its swelling in various structural states is needed.

The excellent swelling resistance of ferritic-martensitic alloys compared to austenitic stainless steels is well proven. The mechanisms of this phenomenon (higher self-diffusion rate, low preference factor for high dislocation density, low rate of helium generation, strong defect capture, microstructural lamellas and subgrains, boundary effects, etc.) are well described in the literature [13]. However, a comparison of the swelling of 9-12 wt. \% Cr ferriticmartensitic steels shows a significant data scattering [14]. The reason for this scatter may be a difference in the structure and composition of the studied steels.

The aim of the study was to optimize the factors of the structural-phase state (grain size, parameters of secondary phase precipitation, degree of decomposition of the solid solution) to increase operational characteristics and to compare the level of swelling for two different structure states. 
To achieve the goal of the study, the following tasks were set:

- to develop a technology for creating an ultrafine-grained structure, which can be used on an industrial scale;

- determine the optimal parameters of deformation and heat treatment to obtain a uniform and stable microstructure;

- to examine the effect of thermomechanical treatment and the type of obtained structures on the radiation tolerance of T91 steel.

\section{MATERIAL AND METHODS}

T91 steel manufactured by INDUSTELL, Belgium (melting: 504/3, heat: 82566-4) was supplied in the form of a $40 \mathrm{~mm}$ thick plate obtained by hot rolling followed by heat treatment. The heat treatment includes normalization at $1040{ }^{\circ} \mathrm{C}$ for 30 minutes, followed by air cooling and then tempering at $730{ }^{\circ} \mathrm{C}$ for 60 minutes with air cooling to room temperature (the so-called N\&T state). The chemical composition of T91 steel is shown in Table 1.

Table 1.

The chemical composition of T91, (wt.\%)

\begin{tabular}{|c|c|c|c|c|c|c|c|c|}
\hline$F e$ & $C r$ & $M o$ & $M n$ & $S i$ & $V$ & $N i$ & $N b$ & $C u$ \\
\hline bulk & 8.76 & 0.862 & 0.597 & 0.317 & 0.186 & 0.099 & 0.073 & 0.054 \\
\hline$A l$ & $C$ & $N$ & $P$ & $S$ & $S n$ & $B$ & $C o$ & $A s$ \\
\hline 0.021 & 0.088 & 0.003 & 0.019 & 0.0006 & 0.005 & 0.0001 & 0.019 & 0.007 \\
\hline
\end{tabular}

In the present study the multi-cycle "upsetting-extrusion" method was chosen to carry out the SPD. The method was developed in NSC KIPT and it has proved itself both in laboratory research and in the industrial production of a number of materials with high characteristics $[15,16]$. This method consists in multiple reiterations of operations of upsetting and extrusion on a hydraulic press ДБ 2432 with a force of $160 \mathrm{tf}$. The method is described in more detail in [17].

Deformation was carried out in two temperature regions: austenitic-ferritic at a temperature $870{ }^{\circ} \mathrm{C}$ and ferritic at temperatures $750-575{ }^{\circ} \mathrm{C}$. Samples with a $20 \mathrm{~mm}$ diameter and a $60 \mathrm{~mm}$ height were subjected to upsetting to a diameter $30 \mathrm{~mm}$ and then again extruded to a diameter of $20 \mathrm{~mm}$.

"Upsetting-extrusion" cycles in the ferritic region were carried out with a gradual decrease in the deformation temperature from $750{ }^{\circ} \mathrm{C}$ on the first cycle to $575^{\circ} \mathrm{C}$ on the last, fifth cycle. In general, the temperature regime of the "upsetting-extrusion" cycles was as follows: 750-700-650-635-575 ${ }^{\circ} \mathrm{C}$.

To determine the stability of microstructures formed as a result of SPD, heat treatments were carried out in the temperature range $550-750^{\circ} \mathrm{C}$ for $1-50$ hours.

Understanding the evolution of the microstructure during irradiation and its effect on the decline of mechanical properties is of a paramount importance. Neutron irradiation has several disadvantages, including high cost, residual activity, and prolonged irradiation of samples. Furthermore, many nuclear facilities, such as FFTF, RAPSODIE, DFR, PFR, Superfenix, EBR-II, BR-10, BN-350, etc. - are shut down.

The applying of heavy ion implantation to simulate neutron irradiation in a reactor is common practice by reason of the high rate of achievement of relatively high levels of damage and the absence of induced radioactivity.

Samples of steel T91 in the initial state (martensitic structure) and after severe plastic deformation (ferritic structure) were irradiated with argon ions with energy $1.4 \mathrm{MeV}$ to a dose $120 \mathrm{dpa}$ at a temperature $460{ }^{\circ} \mathrm{C}$. This irradiation temperature was chosen due to the fact that the peak of temperature swelling for steel T91 falls on $\sim 460{ }^{\circ} \mathrm{C}$. All irradiations were carried out using the acceleration-measuring system "ESU-2" containing the Van de Graaff accelerator. The depth distribution of Ar atoms concentration and damage was calculated by SRIM 2008 [18] (Fig. 1). Damage calculations are based on the Kinchin-Pease model, with a displacement energy of $40 \mathrm{eV}$ for $\mathrm{Fe}$ and $\mathrm{Cr}$, as recommended in ASTM E521-96 (2009) [19].

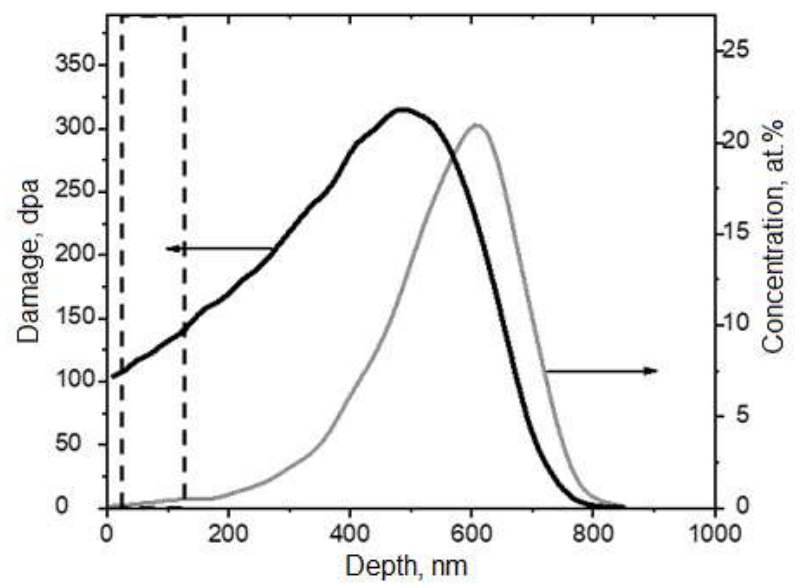

Figure 1. Calculated profiles of damages and concentrations of 1.4 MeV Ar ions implanted in T91 steel to a dose of $5 \times 10^{17} \mathrm{~cm}^{-2}$. The area of study is marked with a dash. 
The steel structure was studied by metallography and electron microscopy using electron microscopes JEM100CX and JEM-2100. Microhardness was measured on a semi-automatic microindenter LM 700AT at a load $200 \mathrm{~g}$.

\section{RESULTS AND DISSCUSSION}

The microstructure of T91 steel in initial state is shown in Fig. 2. The structural state of tempered martensite is characterized by the presence of prior austenite grain boundaries. These boundaries are decorated with $\mathrm{M}_{23} \mathrm{C}_{6}$ carbide precipitates. The prior austenite grain size is about $20 \mu \mathrm{m}$, the size (thickness) of $\mathrm{M}_{23} \mathrm{C}_{6}$ precipitates varies from about 100 to $200 \mathrm{~nm}$. Inside the prior austenite grains, martensitic lamellas with a transverse size of $0.25-0.5 \mu \mathrm{m}$ are observed.

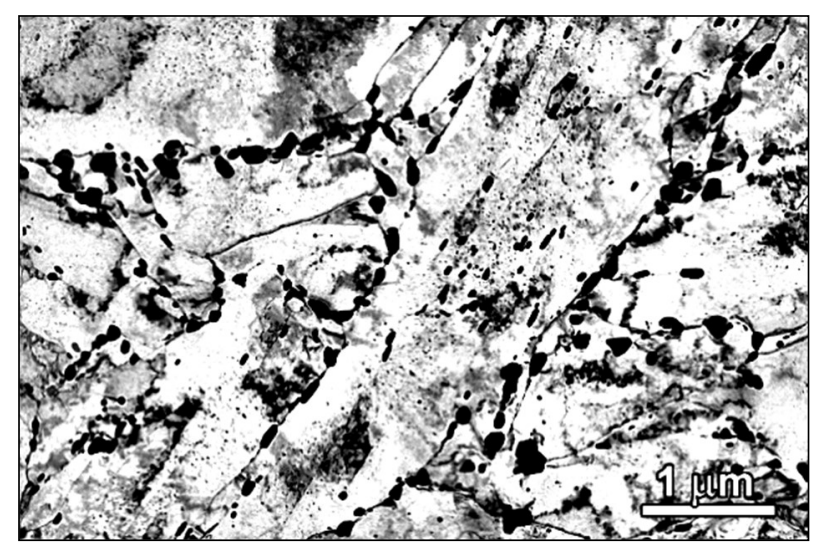

a

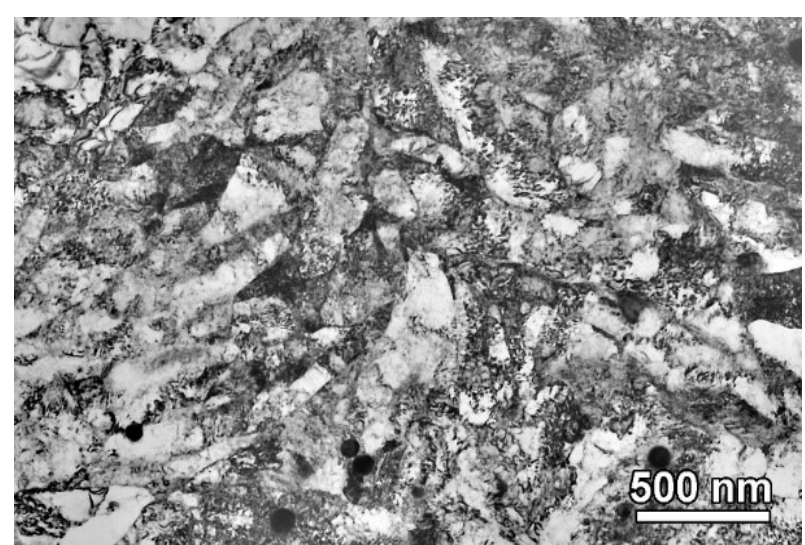

b

Figure 2. The microstructure of steel T91: a - in initial state, b - after 3 cycles of "upsetting-extrusion" at $870{ }^{\circ} \mathrm{C}$

The finely dispersed microstructure of steel after 3 cycles of "upsetting-extrusion" at a temperature $870{ }^{\circ} \mathrm{C}$ belongs to the martensitic-ferritic type (Fig. 2b). From a comparison of Fig. 2a and b, it can be seen that the SPD led to a significant refinement of the martensitic structure.

The microstructure that formed after treatment in the ferritic range with a gradual decrease in temperature and the ferrite grains size distribution are shown in Fig. 3. The average grain size was $145 \mathrm{~nm}$.

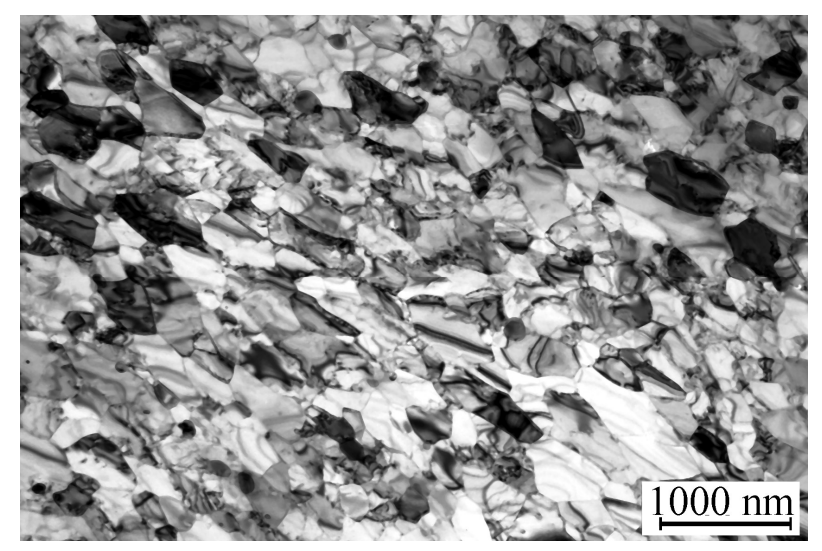

a

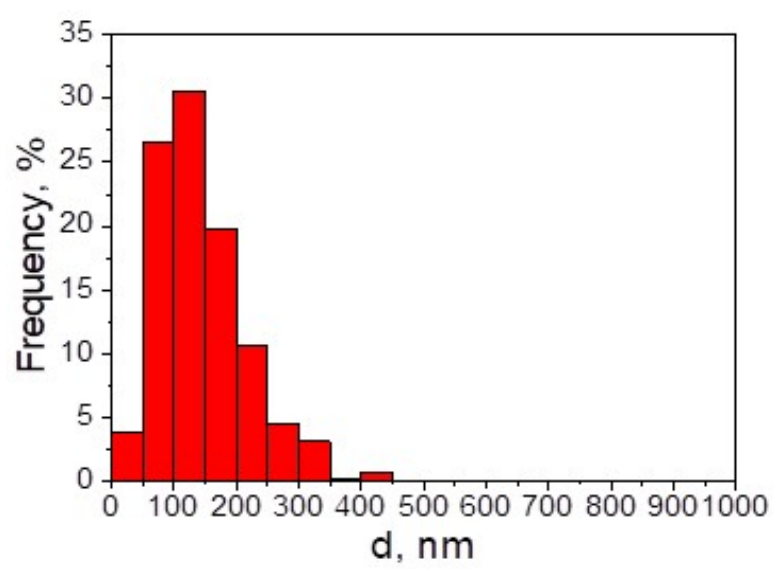

$\mathrm{b}$

Figure 3. The microstructure of steel after 5 cycles of "upsetting-extrusion"in the ferritic range (a) and grain size distribution (b)

The results of the microhardness measuring of the samples after heat treatment in the temperature range of $550-750{ }^{\circ} \mathrm{C}$ for $1-50$ hours showed that high mechanical characteristics are maintained during exposure at a temperature of $550{ }^{\circ} \mathrm{C}$. It was found, that, the temperature of $550{ }^{\circ} \mathrm{C}$ is the optimal regime for tempering, which allow to stabilize the structure, since at higher temperatures there is recrystallization and, as a result, a decrease in hardness. Therefore, for further studies, a sample that underwent heat treatment for 25 hours at a temperature of $550{ }^{\circ} \mathrm{C}$ was selected. The average grain size for sample with a ferritic structure was $210 \mathrm{~nm}$, and the microhardness was at the level of $2948 \mathrm{MPa}$. The microstructure of the sample is shown in Fig. 4.

To compare the degree of swelling, austenitic steel SS316 was chosen which is now used as a structural material of the current generation of reactors. Herewith, irradiation of SS316 steel was carried out under the following conditions: dose $-80 \mathrm{dpa}$, temperature $-615^{\circ} \mathrm{C}$. The microstructure of irradiated steels is shown in Fig. 5 . For three types of samples, namely, T91 steel with martensitic and ferritic structures and steel SS316 with an austenitic structure, the formation of a void structure is observed. 


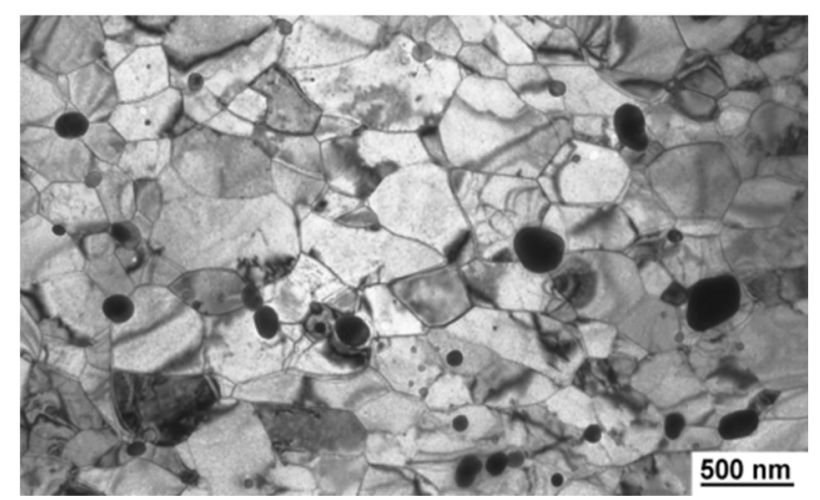

Figure 4. The microstructure of the sample of steel T91 after heat treatment at $550^{\circ} \mathrm{C}$ for $25 \mathrm{~h}$ after the SPD in a ferritic range

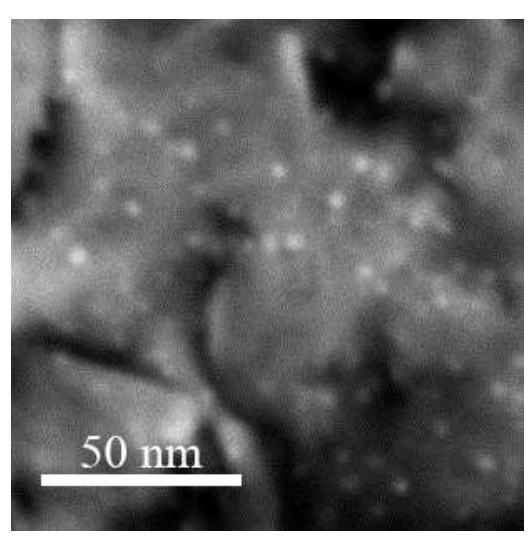

a

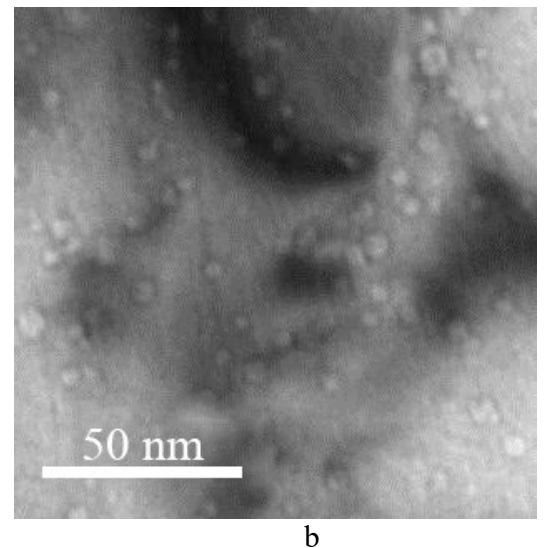

b

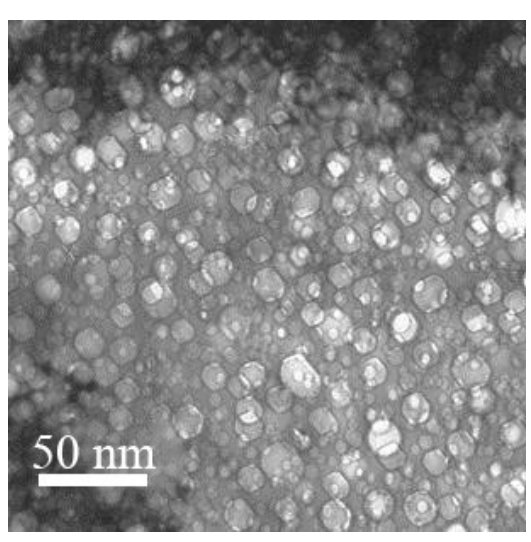

c

Figure 5. The microstructure of steel T91 for samples with martensitic (a) and ferritic (b) structures, irradiated to a dose 120 dpa $\left(\mathrm{E}=1,4 \mathrm{MeV} \mathrm{Ar}^{+}\right)$at $460^{\circ} \mathrm{C}$ and austenitic steel SS316, irradiated to a dose $80 \mathrm{dpa}$ at $615^{\circ} \mathrm{C}(\mathrm{c})$

Using experimentally determined parameters of a void structure, the swelling value $\mathrm{S}$ was calculated by the formula (1):

$$
S=\frac{\frac{\pi}{6 \cdot A \cdot h} \sum_{i=1}^{N} d_{i}^{3}}{1-\frac{\pi}{6 \cdot A \cdot h} \sum_{i=1}^{N} d_{i}^{3}} \cdot 100 \%
$$

where $\mathrm{d}_{\mathrm{i}}$-diameter of $\mathrm{i}$-th void; $\mathrm{N}$ - the number of voids on the image; A- area of the image with which the calculations were carried out; h- sample foil thickness.

The parameters of void structure and the magnitude of the swelling are shown in Table 2.

Diameter d, number density $\rho$ of voids and swelling values $\mathrm{S}$

Table 2.

\begin{tabular}{|c|c|c|c|}
\hline Sample & $\mathrm{d}, \mathrm{nm}$ & $\rho, 1 / \mathrm{m}^{3}$ & $\mathrm{~S}, \%$ \\
\hline T91 Martensitic & 2,9 & $1 \times 10^{23}$ & 0,26 \\
\hline T91 Ferritic & 6,6 & $5,8 \times 10^{22}$ & 0,65 \\
\hline SS316 Austenite & 18 & $9,3 \times 10^{21}$ & 15,6 \\
\hline
\end{tabular}

A comparison of the steel with a martensitic and ferritic structure (Fig. 5 a, b) showed that the level of swelling of the sample in the martensitic state is 2.5 times lower than in the ferritic state. It should be noted that the swelling of the ferritic structure (BCC) is 24 times less than the austenitic structure (FCC). Such a large difference in the levels of swelling is associated with the difference in the types of crystal lattices of these materials, and as a result, with different mechanisms of the development of radiation damage.

In [14], data on the swelling of ferritic-martensitic steels irradiated with neutrons up to a dose of 208 dpa in a temperature range from 400 to $443{ }^{\circ} \mathrm{C}$ were compared (Fig. 6). Let's note several key features. There is a general tendency to swelling at a rate of $\sim 0.01 \% / \mathrm{dpa}$, although the data are very scattered. In general, there is a large difference in swelling between alloys (HT9 and T91), though T91 tends to swell more for a given level of damage. Finally, the swelling of HT9 steel of the same heat of 9607R2, but of different heat treatment, differs by an order of 
magnitude (see Fig. 6). Our data - indicated by a triangle and a star in a dashed rectangle - show that the scatter may be due to the different microstructure states that form before irradiation (ferrite $(\star)$ or martensite $(\boldsymbol{\Delta})$ ).

Further studies are needed to study the level of swelling at even higher radiation doses.

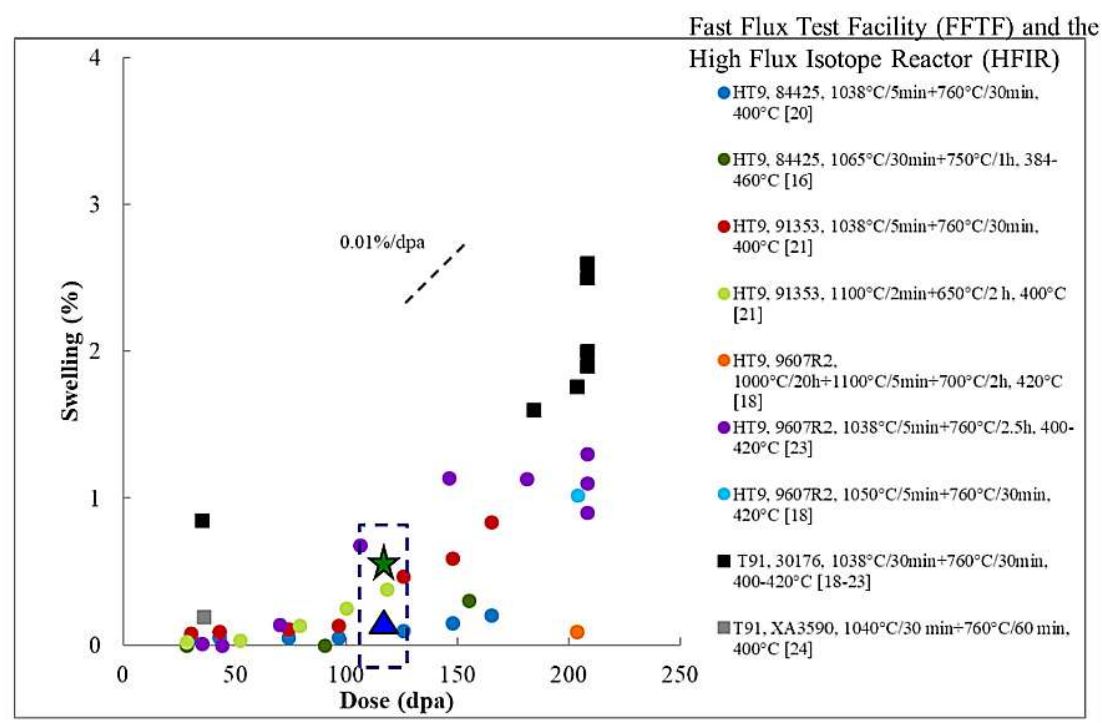

Figure 6. Generalized data for steels HT9 and T91 irradiated in a reactor to a dose $208 \mathrm{dpa}$ at temperatures from 400 to $443^{\circ} \mathrm{C}$ [14]

\section{CONCLUSIONS}

The effect of thermomechanical treatment on the type of obtained structures of T91 steel is investigated. It was shown that the receiving of a nanostructure can be achieved by severe plastic deformation method. The factors of the structural-phase state of T91 martensitic steel have been optimized during thermomechanical treatment by the method of multiple "upsetting-extrusion". The optimal parameters of deformation and temperature regimes for obtaining a uniform ultrafine-grained structure are determined.

Severe plastic deformation combined with heat treatment allows to reduce the average grain size. After 5 cycles of multiple "upsetting-extrusion" in the ferritic range, the minimum average grain size of $\sim 140 \mathrm{~nm}$ was achieved. The average grain size of the initial steel (martensitic structure) is $20 \mu \mathrm{m}$.

A study of the development of void structure after irradiation of steel T91 in various structural states was carried out. It was shown that after irradiation with $\mathrm{Ar}$ ions with an energy $1.4 \mathrm{MeV}$ to a dose $120 \mathrm{dpa}$ at $\mathrm{T}=460{ }^{\circ} \mathrm{C}$, the swelling in the ultrafine-grained ferritic structure is $0.65 \%$ compared with $0.26 \%$ for the initial martensitic structure, which confirms the influence of structural-phase state of steel T91 on its swelling.

The swelling of steel with an austenitic structure is $\sim 15.6 \%$, which is 24 times more than the level of swelling of steel with a ferritic structure.

\section{ACKNOWLEDGMENT}

The authors are very much appreciated to Dr. Marta Serrano Garcia (e-mail: marta.serrano@ciemat.es) from Centro Investigaciones Energéticas, Medioambientales y Tecnológicas (Madrid, Spain) for the provided materials and productive cooperation.

\section{ORCID IDs}

(DVictor Voyevodin, https://orcid.org/0000-0003-2290-5313; (D) Mikhail Tikhonovsky https://orcid.org/0000-0001-5889-0366, DGalyna Tolstolutska https://orcid.org/0000-0003-3091-4033; DHanna Rostova https://orcid.org/0000-0003-1329-9016, (D) Ruslan Vasilenko https://orcid.org/0000-0002-4029-9727; (DOleksandr Kalchenko https://orcid.org/0000-0003-0856-1868, (D)Natalya Andrievska https://orcid.org/0000-0001-5326-4235; DOleksii Velikodnyi https://orcid.org/0000-0001-5088-6143

\section{REFERENCES}

[1] R. Klueh and D. Harries, High-Chromium Ferritic and Martensitic Steels for Nuclear Applications, ed. (ASTM International, West Conshohocken, 2001), pp. 221, https://doi.org/10.1520/MONO3-EB.

[2] R. Klueh, Philosophical Magazine. 98(2012), 2618-2636 (2008), https://doi.org/10.1080/14786435.2018.1497307.

[3] S. Baindur, Bulletin of the Canadian Nuclear Society, 29(1), 32-38 (2008).

[4] https://www.astm.org/Standards/A213.htm.

[5] M. Song, C. Sun, Z.Fan, Y. Chen, R.Zhu, K.Y. Yu, K.T. Hartwig, H.Wang, and X.Zhang, Acta Materialia, 112, 361-377 (2016), https://doi.org/10.1016/j.actamat.2016.04.031.

[6] R.A. Andrievskii, The Physics of Metals and Metallography. 110(3), 229-240 (2010), https://doi.org/10.1134/S0031918X10090061.

[7] M.V. Karavaeva, M.A. Nikitina, A.V. Ganeev, R.K. Islamgaliev, IOP Conf. Series: Materials Science and Engineering. 179, 012037 (2017), https://doi.org/10.1088/1757-899X/179/1/012037. 
[8] D.C. Foley, K.T. Hartwig, S.A. Maloy, P. Hosemann, X. Zhang, Journal of Nuclear Materials. 389, 221-224 (2009), http://doi.org/10.1016/j.jnucmat.2009.02.005.

[9] Z.Q. Fan, T. Hao, S.X. Zhao, G.N. Luo, C.S. Liu, Q.F. Fang, Journal of Nuclear Materials. 434, 417-421 (2013), https://doi.org/10.1016/j.jnucmat.2012.12.009.

[10] D.S. Gelles, Journal of Nuclear Materials. 233-237, 293-298 (1996), https://doi.org/10.1016/S0022-3115(96)00222-X.

[11] J.J. Kai, R.L. Klueh, Journal of Nuclear Materials. 230, 116-123 (1996), https://dx.doi.org/10.1016/0022-3115(96)00165-1.

[12] J. Van Den Bosch, O. Anderoglu, R. Dickerson, M. Hartl, et al., Journal of Nuclear Materials. 440, 91-97 (2013), https://dx.doi.org/10.1016/j.jnucmat.2013.04.025.

[13] M.B. Toloczko, F.A. Garner, C.R. Eiholzer, Journal of Nuclear Materials. 215, 604-607 (1994), https://doi.org/10.1016/00223115(94)90131-7.

[14] E. Getto, K. Sun, A.M. Monterrosa, et al., Journal of Nuclear Materials. 480, 159-176 (2016), https://doi.org/10.1016/j.jnucmat.2016.08.015.

[15] O.V. Chorniy, Ya.D. Starodybov, O.I. Volchok, G.E. Storozhilov, Patent Ukraine No. 42487 A (15 January 2001). (in Ukrainean)

[16] I.I. Papirov, G.F. Tikhinskiy, The Physics of Metals and Metallography. 29(5), 1057-1060 (1970). (in Russian)

[17] V.M. Azhazha, O.V. Chorniy, G.E. Storozhilov, N.F. Andrievskaya, T.U. Rydicheva, Problems of Atomic Science and Technology, Series: "Vacuum, Pure Materials, Superconductors", 6(14), 136 -139 (2004). (in Russian)

[18] J.F. Ziegler, Version - SRIM-2008.04, www.srim.org.

[19] ASTM E521-96, Standard Practice for Neutron Radiation Damage Simulation by Charged-Particle Irradiation, https://www.astm.org/DATABASE.CART/HISTORICAL/E521-96.htm.

\section{СТРУКТУРНІ ОСОБЛИВОСТІ ТА ЕКСПЛУАТАЦЙНІ ХАРАКТЕРИСТИКИ СТАЛІ Т91 \\ В.М. Восводін, М.А. Тихоновський, Г.Д. Толстолуцька, Г.Ю. Ростова, Р.Л. Василенко, \\ О.С. Кальченко, Н.Ф. Андрієвська, О.М. Великодний \\ Національний науковий центр «Харківський фізико-технічний інститут» вул. Академічна 1, Харків 61108, Україна}

Досліджено мікроструктуру і радіаційну стійкість мартенситної сталі Т91 після термомеханічної обробки. Розроблено фізико-технологічні основи процесу створення наноструктурного стану в реакторній сталі Т91. Ця структура була отримана в результаті інтенсивної пластичної деформації сталі Т91 методом багаторазового «осадження-вичавлювання», розробленим в ННЦ ХФТІ, в двох температурних діапазонах: в області існування аустеніту і з послідовним зниженням температури деформації і збільшенням циклів «осадження-вичавлювання» в області існування фериту. Для подальшої термообробки були обрані особливі температурний діапазон і режими деформації для отримання оптимальної структури. Також була знайдена оптимальна температура відгартовування для отримання однорідної структури. Було виявлено, що середній розмір зерна сталі Т91 зменшується з 20 мкм в вихідному стані до 140 нм після 5 циклів «осадження-вичавлювання» в феритному інтервалі і до 100 нм після 3 циклів деформації в аустенітній області. Було встановлено, що зі збільшенням кількості циклів і зниженням температури деформації відбувається підвищення ступеню однорідності розподілу зерен за розмірами. В цьому випадку мікротвердість збільшується з 2090 МПа до 2850 МПа після 5 циклів «осадження-вичавлювання» в феритному інтервалі. В аустенітній області значення мікротвердості збільшуються 33400 до 3876 МПа. Визначено розпухання сталі Т91 в двох структурних станах - мартенситному та ферритному. Так, розпухання сталі при високій дозі опромінення іонами аргону з енергією $1,4 \mathrm{MeB}\left(120\right.$ зсувів на атом, температура опромінення $\left.460^{\circ} \mathrm{C}\right)$ становить $\Delta \mathrm{V} / \mathrm{V}=$ $0.26 \%$ в вихідному стані (мартенситна структура) і 0,65\% для зразків 3 феритною структурою.

КЛЮЧОВІ СЛОВА: мартенситна сталь, термомеханічна обробка, мікротвердість, наноструктура, інтенсивна пластична деформація, радіаційна стійкість.

\section{СТРУКТУРНЫЕ ОСОБЕННОСТИ И ЭКСПЛУАТАЦИОННЫЕ ХАРАКТЕРИСТИКИ СТАЛИ Т91 \\ В.Н. Воеводин, М.А. Тихоновский, Г.Д. Толстолуцкая, А.Ю. Ростова, И.Е. Копанец, Р.Л. Василенко, А.С. Кальченко, Н.Ф. Андриевская, А.Н. Великодный \\ Национальный научный цеентр «Харьковский физико-технический институт» ул. Академическая 1, Харьков 61108, Украина}

Исследована микроструктура и радиационная стойкость мартенситной стали Т91 после термомеханической обработки. Разработаны физико-технологические основы процесса создания наноструктурного состояния в реакторной стали Т91. Эта структура была получена в результате интенсивной пластической деформации стали Т91 методом многократной «осадкивыдавливания», разработанным в ННЦ ХФТИ, в двух температурных диапазонах: в области существования аустенита и с последовательным снижением температуры деформации и увеличением циклов «осадки-выдавливания» в области существования феррита. Для дальнейшей термообработки были выбраны особые температурный диапазон и режимы деформации для получения оптимальной структуры. Также была найдена оптимальная температура отпуска для получения однородной структуры. Было обнаружено, что средний размер зерна стали Т91 уменьшается с 20 мкм в исходном состоянии до $\sim 140$ нм после 5 циклов «осадки-выдавливания» в ферритном интервале и до $~ 100$ нм после 3 циклов деформации в аустенитной области. Было установлено, что с увеличением числа циклов и уменьшением температуры деформации происходит повышение степени однородности распределения зерен по размерам. В этом случае микротвердость увеличивается с 2090 МПа до 2850 МПа после 5 циклов «осадки-выдавливания» в ферритном интервале. В аустенитной области значения микротвердости увеличиваются с 3400 до 3876 МПа. Определено распухание стали Т91 в двух структурных состояниях - мартенситном и ферритном. Так, распухание стали при высокой дозе облучения ионами аргона с энергией 1,4 МэВ (120 смещений на атом, температура облучения $\left.460^{\circ} \mathrm{C}\right)$ составляет $\Delta \mathrm{V} / \mathrm{V}=0.26 \%$ в исходном состоянии (мартенситная структура) и $0,65 \%$ для образцов с ферритной структурой.

КЛЮЧЕВЫЕ СЛОВА: мартенситная сталь, термомеханическая обработка, микротвердость, наноструктура, интенсивная пластическая деформация, радиационная стойкость. 